\title{
Tissue polypeptide specific antigen for the detection of lymphoproliferative diseases induced by cyclosporin
}

Department of Laboratory

Diagnostics, Kaiser Franz Josef

Hospital and Ludwig Boltzmann Institute for Cardiosurgery

Research,

Vienna,

Austria

M Vogl

A Griesmacher

M M Müller

Department of Cardiothoracic

Surgery,

University of Vienna, Austria

M Grimm

W Klepetko

Correspondence to: Dr M Vogl, Department of Laboratory Diagnostics, Kaiser Franz Josef Hospital, Kundratstrasse 3, A-1100 Vienna, Austria.

Accepted for publication 14 June 1995

\author{
M Vogl, A Griesmacher, M Grimm, W Klepetko, M M Müller
}

\begin{abstract}
Aim-To evaluate the efficacy of tissue polypeptide specific (TPS) antigen for the early detection of cyclosporin $A$ (CyA) induced post-transplant lymphoproliferative diseases.

Methods-Serum concentrations of TPS antigen were analysed using a monoclonal enzyme immunoassay and whole blood CyA concentrations were measured using high pressure liquid chromatography. Infection with Epstein-Barr virus and cytomegalovirus was detected by determining levels of IgM and IgG antibodies directed against viral capsid antigen (VCA). Immunohistochemistry and analysis of clonality were carried out on formalin fixed, paraffin wax embedded tissue.
\end{abstract}

Results-The mean serum concentration of TPS antigen in the eight transplant recipients investigated was $60 \mathrm{U} / 1$ during periods without complication (control), $101 \mathrm{U} / \mathrm{l}$ during infection, $166 \mathrm{U} / \mathrm{l}$ when the diagnosis of a lymphoma was confirmed, and $172 \mathrm{U} / \mathrm{l}$ when lymphoma and infection coincided. Increased TPS antigen concentrations were detected in six patients one month before detection of malignancy. After reduction of immunosuppression and the start of tumour regression, TPS antigen concentrations decreased. TPS antigen concentrations increased in the one patient who experienced a recurrence. Conclusions-Continuous monitoring of TPS antigen concentrations leads to the early discovery of CyA induced lymphoprolilferative disease.

(f Clin Pathol 1995;48:1039-1044)

Keywords: Post-transplant lymphoproliferative disease, tissue polypeptide specific antigen, cyclosporin A.

As most post-transplant lymphomas restricted to a single organ resolve following the reduction or discontinuation of immunosuppressive treatment, a specific marker allowing tumour growth to be detected at an early stage would be most useful for effective patient management. For this reason, the postoperative course of 77 heart or lung transplant recipients was investigated between October 1991 and March 1994 at the Department of Cardiothoracic Surgery at the University of Vienna. Eight of the 77 patients, three heart and five lung transplant recipients, developed a posttransplant lymphoproliferative disorder. All were of B lymphocyte origin. One patient also had Epstein-Barr virus (EBV) infection and two others were infected with cytomegalovirus (CMV). All eight patients received cyclosporin A (CyA), prednisolone and azathioprine. In seven patients a reduction in the degree of immunosuppression was followed by regression of the lymphoma.

The link between CyA, the standard immunosuppressant administered to transplant recipients, and the development of post-transplant lymphoproliferative disease is well recognised. ${ }^{1-5}$ The occurrence of these malignancies will probably increase as the number of transplants performed increases and because of the need to keep patients on immunosuppressive drugs for life. Detection of post-transplant lymphoproliferative disease is protracted and difficult, and must be confirmed by biopsy. Post-transplant lymphoproliferative disease has also been associated with EBV infection. ${ }^{6-12}$ The principle of treating posttransplant lymphoproliferative disease by reducing immunosuppression is successful in most cases, often without subsequent loss of graft function. The prognosis of the recipient is more favourable if the CyA dose is reduced at an early stage of tumour development. ${ }^{13}$ Therefore, specific markers to detect, or at least suggest, the development of post-transplant lyphoproliferative disease at an early stage would be of interest. Tissue polypeptide specific (TPS) antigen, an established tumour marker, is the M3 specific epitope of tissue polypeptide antigen. As a part of the cytoskeleton of cells, it is produced during the late $S$ and G2 phases of the cell cycle and released immediately after mitosis. Thus, the release of TPS antigen is a function of cell division and TPS antigen concentrations reflect the proliferative activity of cells. ${ }^{14-16}$

In this retrospective study we analysed TPS antigen serum concentrations in eight transplant recipients, in order to investigate whether monitoring TPS antigen is useful for establishing a diagnosis of post-transplant lymphoproliferative disease. The effectiveness of therapy and the detection of recurrence were also studied.

\section{Methods}

Three heart and five lung transplant recipients, six men and two women, developed post-transplant lymphoproliferative disease between October 1991 and March 1994, 57 to 618 days after transplantation. This is an incidence of 
Table 1 Clinical details of heart and lung transplant recipients with post-transplant lymphoproliferative disease

\begin{tabular}{|c|c|c|c|c|c|c|c|}
\hline $\begin{array}{l}\text { Case } \\
\text { no. }\end{array}$ & $\operatorname{Sex}$ & $\begin{array}{l}\text { Age at } \\
\text { transplantation } \\
\text { (years) }\end{array}$ & Primary disease & $\begin{array}{l}\text { Date and type of } \\
\text { transplant }\end{array}$ & $\begin{array}{l}\text { Days to tumour } \\
\text { development }\end{array}$ & $\begin{array}{l}\text { Days to } \\
\text { involution }\end{array}$ & $\begin{array}{l}\text { Follow up } \\
\text { (days) }\end{array}$ \\
\hline 1 & $\mathbf{M}$ & 59 & $\begin{array}{l}\text { Antero-septal cardiac infarction, } \\
\text { congestive heart failure }\end{array}$ & $\begin{array}{l}01 / 12 / 93 \text { Heart } \\
\text { transplant }\end{array}$ & 105 & 181 & 202 \\
\hline 2 & $\mathbf{M}$ & 33 & $\begin{array}{l}\text { Aortic valve replacement } 1987 \text {, } \\
\text { cardiomyopathy, aortic aneurysm }\end{array}$ & $\begin{array}{l}04 / 27 / 93 \text { Heart } \\
\text { transplant }\end{array}$ & 128 & 250 & 270 \\
\hline 3 & $\mathrm{~F}$ & 21 & Cystic fibrosis & 10/14/91 Lung & 80 & 141 & 826 \\
\hline 4 & $\mathbf{M}$ & 40 & $\begin{array}{l}\text { Chronic obstructive bronchitis } \\
\text { caused by lack of } 1 \text {-anti- } \\
\text { proteinase inhibitor }\end{array}$ & $\begin{array}{l}\text { 11/08/93 Lung } \\
\text { transplant (one) }\end{array}$ & 57 & - & 135 \\
\hline 5 & $\mathbf{M}$ & 55 & $\begin{array}{l}\text { Aortic and bicuspid valve } \\
\text { replacement } 1989 \text {, congestive heart } \\
\text { failure }\end{array}$ & $\begin{array}{l}05 / 23 / 93 \text { Heart } \\
\text { transplant }\end{array}$ & 116 & 205 & 236 \\
\hline 6 & $\mathbf{M}$ & 26 & Pulmonary hypertension & $\begin{array}{l}\text { 09/07/92 Lung } \\
\text { transplant (both) }\end{array}$ & 198 & 240 & 494 \\
\hline 7 & $\mathbf{F}$ & 20 & Lyell syndrome ARDS & $\begin{array}{l}\text { 05/10/92 Lung } \\
\text { transplant (both) }\end{array}$ & 618 & 679 & 690 \\
\hline 8 & $\mathbf{M}$ & 52 & $\begin{array}{l}\text { Chronic obstructive lung disease, } \\
\text { blue bloater, emphysema }\end{array}$ & $\begin{array}{l}\text { 11/08/93 Lung } \\
\text { transplant (both) }\end{array}$ & 91 & - & 129 \\
\hline
\end{tabular}

ARDS = adult respiratory distress syndrome.

Table 2 Clinical presentation of lymphoproliferative disease, organs involved, treatment, and patient outcome

\begin{tabular}{|c|c|c|c|c|}
\hline $\begin{array}{l}\text { Case } \\
\text { no. }\end{array}$ & Clinical presentation & Organs involved & Treatment & $\begin{array}{l}\text { Patient, tumour and graft at the end of } \\
\text { the study }\end{array}$ \\
\hline 1 & Fever, cough, dyspnoea & Multiple sites in both lungs & $\begin{array}{l}\text { CyA dose reduced, steroid dose } \\
\text { increased }\end{array}$ & Alive, tumour free, retained \\
\hline 2 & Fever, inguinal mass & $\begin{array}{l}\text { Multiple sites in spleen, liver, } \\
\text { inguinal nodes }\end{array}$ & $\begin{array}{l}\text { CyA dose reduced, steroid dose } \\
\text { increased }\end{array}$ & Alive, tumour free, retained \\
\hline 3 & Fever, dyspnoea, loss of weight & Single lesion in the left lung & $\begin{array}{l}\text { CyA dose reduced, steroid dose } \\
\text { increased, chemotherapy }\end{array}$ & Alive, tumour free, retained \\
\hline 4 & Fever, cough & Multiple sites in the grafted lung & $\begin{array}{l}\text { CyA dose reduced, steroid dose } \\
\text { increased }\end{array}$ & $\begin{array}{l}\text { Died } 23 / 03 / 94 \text {, progressive PTLD } \\
\text { (at necropsy), ARDS }\end{array}$ \\
\hline 5 & Fever, cough & Single lesion in the left lung & CyA dose reduced, steroid dose & Alive, tumour free, retained \\
\hline 6 & Fever & Multiple sites in both lungs & $\begin{array}{l}\text { CyA dose reduced, steroid dose } \\
\text { increased }\end{array}$ & Alive, tumour free, retained \\
\hline 7 & $\begin{array}{l}\text { Fever, anaemia, melaena, ileus, } \\
\text { perforation of ileum (resected) }\end{array}$ & Multiple sites in small bowel & $\begin{array}{l}\text { CyA dose reduced, steroid dose } \\
\text { increased, chemotherapy }\end{array}$ & Alive, tumour free, retained \\
\hline 8 & Cough, chest pain & Multiple sites in the grafted lung & $\begin{array}{l}\text { CyA dose reduced, steroid dose } \\
\text { increased }\end{array}$ & $\begin{array}{l}\text { Died } 18 / 03 / 94 \text {, PTLD in regression } \\
\text { (at necropsy), acute rejection }\end{array}$ \\
\hline
\end{tabular}

ARDS = adult respiratory distress syndrome; PTLD = post-transplant lymphoproliferative disease.

Table 3 Occurrence of infection after transplantation

\begin{tabular}{|c|c|c|c|c|c|}
\hline \multirow[b]{2}{*}{$\begin{array}{l}\text { Case } \\
\text { no. }\end{array}$} & \multicolumn{2}{|l|}{$E B V$} & \multicolumn{2}{|l|}{$C M V$} & \multirow[b]{2}{*}{ Additional infections } \\
\hline & $\begin{array}{l}\text { Serological state before } \\
\text { transplantation }\end{array}$ & $\begin{array}{l}\text { Infection after } \\
\text { transplantation }\end{array}$ & $\begin{array}{l}\text { Serological state before } \\
\text { transplantation }\end{array}$ & $\begin{array}{l}\text { Infection after } \\
\text { transplantation }\end{array}$ & \\
\hline $\begin{array}{l}1 \\
2 \\
3 \\
4\end{array}$ & $\begin{array}{l}\text { IgG anti-VCA positive } \\
\text { IgG anti-VCA negative } \\
\text { IgG anti-VCA positive } \\
\text { IgG anti-VCA positive }\end{array}$ & $\begin{array}{l}\text { None } \\
\text { None } \\
\text { None } \\
\text { Secondary }\end{array}$ & $\begin{array}{l}\text { IgG anti-VCA positive } \\
\text { IgG anti-VCA negative } \\
\text { IgM and IgG anti-VCA positive } \\
\text { IgG anti-VCA negative }\end{array}$ & $\begin{array}{l}\text { Secondary } \\
\text { Primary } \\
\text { Secondary } \\
\text { None }\end{array}$ & \multirow{3}{*}{$\begin{array}{l}\text { None } \\
\text { Fungal pneumonia } \\
\text { None } \\
\text { Fungal pneumonia, herpes } \\
\text { simplex virus } \\
\text { None } \\
\text { Herpes simplex virus, } \\
\text { candidiasis } \\
\text { Candidiasis } \\
\text { Fungal pneumonia }\end{array}$} \\
\hline $\begin{array}{l}5 \\
6\end{array}$ & $\begin{array}{l}\text { IgG anti-VCA negative } \\
\text { IgG anti-VCA negative }\end{array}$ & $\begin{array}{l}\text { None } \\
\text { None }\end{array}$ & $\begin{array}{l}\text { IgG anti-VCA negative } \\
\text { IgG anti-VCA negative }\end{array}$ & $\begin{array}{l}\text { Secondary } \\
\text { Primary }\end{array}$ & \\
\hline $\begin{array}{l}7 \\
8\end{array}$ & $\begin{array}{l}\text { IgG anti-VCA negative } \\
\text { IgG anti-VCA positive }\end{array}$ & $\begin{array}{l}\text { None } \\
\text { None }\end{array}$ & $\begin{array}{l}\text { IgG anti-VCA positive } \\
\text { IgG anti-VCA positive }\end{array}$ & $\begin{array}{l}\text { Secondary } \\
\text { Secondary }\end{array}$ & \\
\hline
\end{tabular}

$10.4 \%$ over 30 months in a group of 77 heart/ lung transplant recipients. The patients were 20 to 59 years old at the time of transplantation. Donor-recipient tissue matching was random in all cases.

Patient demographics, indications for transplantation, type and date of transplant procedure, tumour incidence, and days of follow up are given in table 1 . Clinical presentation of post-transplant lymphoproliferative disease, organs involved, therapy, and outcome are shown in table 2 .

\section{IMMUNOSUPPRESSIVE TREATMENT}

All patients received standard immunosuppressive therapy, comprising CyA (whole blood target concentrations $250-400 \mathrm{ng} / \mathrm{ml}$ measured by high pressure liquid chromatography), azathioprine $(2 \mathrm{mg} / \mathrm{kg} /$ day, down to a leucocyte count of 4000 cells $/ \mathrm{ml}$ ) and prednisolone $(500 \mathrm{mg}$ methylprednisolone given intravenously every eight hours for 24 hours postoperatively; $125 \mathrm{mg}$ methylprednisolone given intravenously, beginning on the second day after surgery; and hydroxyprednisolone $2 \mathrm{mg} / \mathrm{kg} /$ day tapered down to a maintenance dose of $0.2 \mathrm{mg} / \mathrm{kg} /$ day by seven days after transplantation). Induction therapy comprised antithymocyte globuline (Thymoglobuline Merrieux $2.5 \mathrm{mg} / \mathrm{kg} /$ day in heart transplant recipients and ATG Fresenius $10 \mathrm{mg} / \mathrm{kg} /$ day in lung transplant recipients) until target blood concentrations of CyA were reached.

When the diagnosis of post-transplant lymphoproliferative disease was confirmed, the CyA dose was reduced (depending on preliminary values to $50-100 \mathrm{ng} / \mathrm{ml}$ ); at the same time the prednisolone dose was increased to 
Table 4 Histological features in patients with post-transplant lymphoproliferative disease

\begin{tabular}{|c|c|c|c|c|}
\hline $\begin{array}{l}\text { Case } \\
\text { no. }\end{array}$ & Histological diagnosis & Clonality & $E B V D N A$ & $C M V D N A$ \\
\hline 1 & Plasmacytoid B cell hyperplasia & Polyclonal & - & Negative \\
\hline 2 & Plasmacytoid B cell hyperplasia & Polyclonal & - & Negative \\
\hline 3 & $\begin{array}{l}\text { Highly malignant large cell non-Hodgkin's } \\
\text { lymphoma with extended necrosis }\end{array}$ & $\begin{array}{l}\text { Monoclonal } \lambda \text {. Predominant heavy chain: } \\
\text { IgM }\end{array}$ & - & Negative \\
\hline 4 & Polymorphic malignant lymphoma & Polyclonal & $\begin{array}{l}\text { Positive in lymphoid cells of } \\
\text { lymphoproliferative tissue }\end{array}$ & - \\
\hline 5 & Polymorphic malignant lymphoma & $\begin{array}{l}\text { Monoclonal } \lambda \text {. Predominant heavy chain: } \\
\text { IgA }\end{array}$ & - & $\begin{array}{l}\text { Positive in lymphoid cells of } \\
\text { lymphoproliferative tissue }\end{array}$ \\
\hline 6 & Polymorphic malignant lymphoma & Polyclonal & - & Negative \\
\hline 7 & $\begin{array}{l}\text { Highly malignant polymorphic non-Hodgkin's } \\
\text { lymphoma }\end{array}$ & Indeterminate & - & Negative \\
\hline 8 & Polymorphic malignant lymphoma & Polyclonal & - & $\begin{array}{l}\text { Positive in macrophages of } \\
\text { lymphoproliferative tissue }\end{array}$ \\
\hline
\end{tabular}

a maintenance dose of $30 \mathrm{mg} /$ day. Frequent biopsies were performed to monitor for rejection.

\section{DETECTION OF INFECTION}

In all eight cases EBV VCA and CMV IgM and IgG antibody titres were determined both before and after transplantation. After transplantation primary infection was noted when the patient became seropositive for VCA IgM

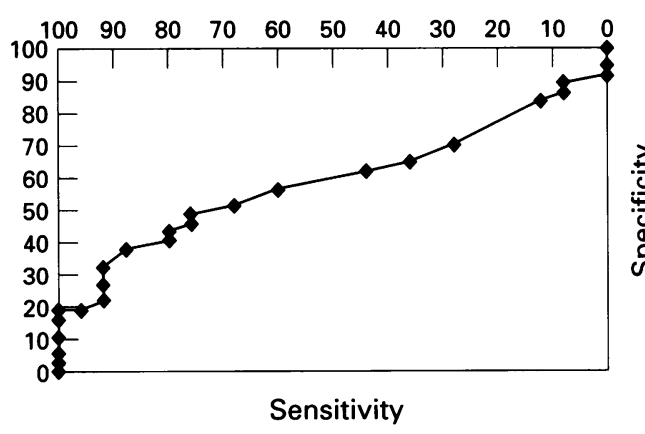

Figure 1 ROC curve: control $\mathrm{v}$ infection.

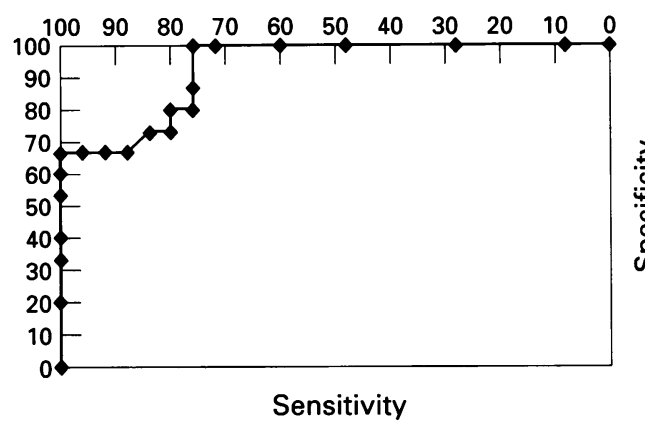

Figure 2 ROC curve: control $\mathrm{v}$ lymphoma.

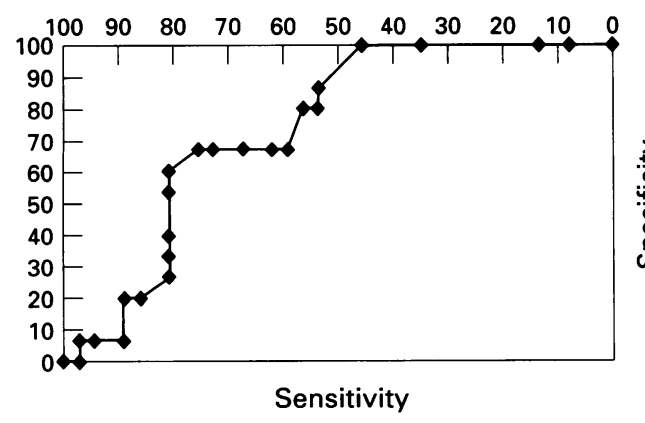

Figure 3 ROC curve: infection $\mathrm{v}$ lymphoma. and IgG. Secondary infection was diagnosed when pre-existing IgG anti-VCA titres rose more than fourfold following transplantation (table 3).

\section{IMMUNOHISTOCHEMISTRY AND ANALYSIS OF}

CLONALITY

Biopsy specimens of the organs involved were available in all eight cases. The biopsy specimens were fixed in formalin, embedded in paraffin wax, stained, and examined by light microscopy. Sections were also analysed for cytoplasmic immunoglobulins (light and heavy chains); $\kappa: \lambda$ light chain ratios were calculated on the basis of a count of 200 mononuclear cells per slide (a $\kappa: \lambda$ or $\lambda$ : $\kappa$ ratio of $10: 1$ or greater was suggestive of monoclonal proliferation). In cases infected with EBV or CMV when post-transplant lymphoproliferative disease was diagnosed, hybridisation studies were performed to identify EBV or CMV DNA in the lymphoproliferative tissues (table 4).

\section{SERUM SAMPLES}

TPS antigen concentrations were determined in 112 serum samples collected during the study period. Samples obtained during the first nine days after surgical intervention or during periods of liver or kidney impairment were excluded. Impaired liver or kidney function was diagnosed when the values of the parameters listed below were higher than the normal reference values, as quoted: bilirubin, $22.2 \mathrm{~mol} / \mathrm{l}$; aspartate aminotransferase, $18 \mathrm{U} / 1$; alanine aminotransferase, $22 \mathrm{U} / \mathrm{l}$; alkaline phosphatase, $190 \mathrm{U} / \mathrm{l} ; \gamma$-glutamyl transferase, $28 \mathrm{U} / \mathrm{l}$; creatinine, $132.6 \mathrm{~mol} / \mathrm{l}$; and blood urea nitrogen, $7 \cdot 1 \mathrm{mmol} / 1$. All specimens were obtained during routine examination, every day in the first week after surgical intervention or when a pathological event was suspected, every second day in the following two weeks and once a week after discharge. Once taken, the samples were centrifuged for 10 minutes at $1500 \mathrm{rpm}$. The supernatant was removed, immediately frozen and stored at $-20^{\circ} \mathrm{C}$. On the day of analysis, the 112 samples were thawed at room temperature, thoroughly mixed for 30 seconds, centrifuged at $3000 \mathrm{rpm}$ for 15 minutes, and specimens from the middle portion of samples were analysed.

The 112 samples (seven to 19 samples from each recipient) were attributed retrospectively 
Table 5 TPS antigen concentrations

\begin{tabular}{llcccc}
\hline Group & No. of observations & Mean & Median & $S D$ & \multicolumn{1}{c}{$S E$} \\
\hline Controls & 32 & 60 & $51 \cdot 0$ & $37 \cdot 7$ & $7 \cdot 5$ \\
Infection & 49 & $101^{*}$ & $70 \cdot 0$ & $76 \cdot 1$ & $12 \cdot 5$ \\
Lymphoma & 20 & $166 \dagger$ & $174 \cdot 0$ & $59 \cdot 5$ & $15 \cdot 4$ \\
Infection + lymphoma & 11 & $172 \ddagger$ & $166 \cdot 0$ & $99 \cdot 7$ & $33 \cdot 3$ \\
\hline
\end{tabular}

* $p<0.0075 ; \uparrow p<0.0001 ; \ddagger p<0.0097$.
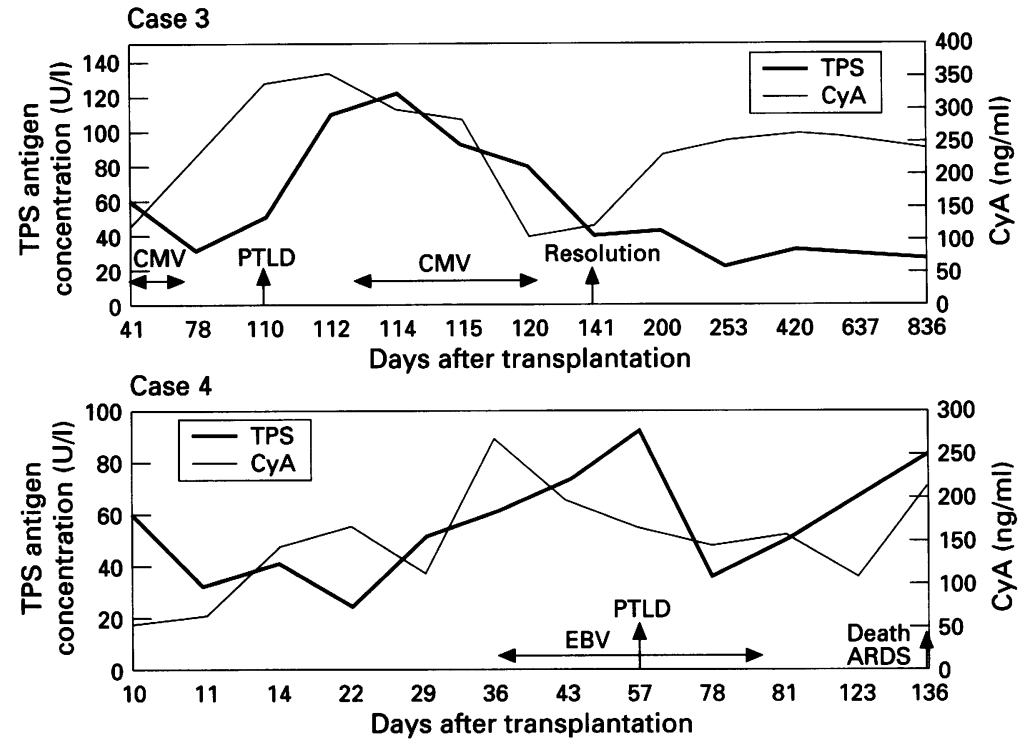

Figure 4 TPS antigen and CyA concentrations in cases 1 and 2. PTLD=post transplant lymphoproliferative disease; $A R D S=$ adult respiratory distress syndrome.

to one of four groups, taking clinical states, radiological findings, serological studies, and histological investigations into consideration. The four groups are as follows: (1) samples collected during periods without complication (control); (2) samples taken during infection; (3) samples collected when the diagnosis of post-transplant lymphoproliferative disease was confirmed; and (4) samples obtained when infection and post-transplant lymphoproliferative disease coincided

\section{MEASUREMENT OF TPS ANTIGEN AND CYA CONCENTRATIONS}

TPS antigen serum concentrations were determined using an in vitro monoclonal enzyme immunoassay (Beki Diagnostics, Bromma, Sweden; intra-assay precision $3 \cdot 8 \%$, interassay $5.8 \%$ ) adapted for a Cobas Core analyser system (Roche Diagnostic Systems, Basel, Switzerland). The calibrations were performed using the standards supplied. The mean (SD) TPS antigen concentration in healthy subjects is $35(30) \mathrm{U} / 1$.
To determine CyA concentrations, blood was collected, between CyA doses, into tubes containing EDTA. CyA concentrations in whole blood were analysed within three hours of venepuncture using high pressure liquid chromatography (BioRad, Richmond, California, USA; intra-assay precision $3 \cdot 1 \%$, interassay precision $5 \cdot 9 \%$ ).

\section{STATISTICAL ANALYSIS}

One way analysis of variance and the Student's $t$ test were used to test the significance of differences between groups; $\mathrm{p}<0.05$ was regarded as significant.

\section{Results}

The average time to the development of posttransplant lymphoproliferative disease was 174 days (5.8 months) (range 57-618 days). In four cases post-transplant lymphoproliferative disease presented primarily in the allograft. Six cases had multifocal lesions and two had single lesions. Widespread post-transplant lymphoproliferative disease in the grafted lung of case 4 resulted in death from adult respiratory distress syndrome. Case 8 died of an acute rejection episode in response to the reduction in immunosuppression; an attempt to increase the CyA dosage was unsuccessful. In two cases (cases 3 and 7) highly malignant post-transplant lymphoproliferative disease resolved on treatment with additional chemotherapy ( $2 \mathrm{mg}$ vincristine, $39 \mathrm{mg}$ doxorubicine, $1170 \mathrm{mg}$ cyclophosphamide). One of these cases subsequently underwent surgical resection of the small bowel. In six of eight cases a reduction in immunosuppression led to prompt resolution. The mean time to tumour involution was 75 days $(2.5$ months) (range 42-122 days).

TPS antigen serum concentrations are presented in table 5. Mean values in cases with infection or post-transplant lymphoproliferative disease or infection and post-transplant lymphoproliferative disease were significantly higher than in controls; the SDs within the three former groups were high.

Diagnostic validities, Youden indices ((sensitivity + specificity) -1$)$ and the number of true/false positive and true/false negative observations are presented in table 6 . Specificities in all of the groups defined were acceptable but the sensitivities were rather low; a value of $67 \%$ was reached for controls $v$ lymphoma only. These results are also illustrated as Youden indices.

Receiver operating characteristic (ROC) plots for controls $v$ infection, controls $v$ lymphoma and infection $v$ lymphoma are shown in

Table 6 Diagnostic validities

\begin{tabular}{|c|c|c|c|c|c|c|c|}
\hline Group & $\begin{array}{l}\text { Sensitivity } \\
(\%)\end{array}$ & $\begin{array}{l}\text { Specificity } \\
(\%)\end{array}$ & $\begin{array}{l}\text { Youden } \\
\text { Index }\end{array}$ & $\begin{array}{l}\text { True } \\
\text { positive }\end{array}$ & $\begin{array}{l}\text { True } \\
\text { negative }\end{array}$ & $\begin{array}{l}\text { False } \\
\text { positive }\end{array}$ & $\begin{array}{l}\text { False } \\
\text { negative }\end{array}$ \\
\hline $\begin{array}{l}\text { Control } v \text { infection } \\
\text { Control } v \text { lymphoma } \\
\text { Infection } v \text { lymphoma }\end{array}$ & $\begin{array}{l}46 \\
67 \\
20\end{array}$ & $\begin{array}{l}80 \\
83 \\
89\end{array}$ & $\begin{array}{l}0.26 \\
0.50 \\
0.09\end{array}$ & $\begin{array}{r}22 \\
13 \\
4\end{array}$ & $\begin{array}{l}26 \\
30 \\
44\end{array}$ & $\begin{array}{l}7 \\
3 \\
5\end{array}$ & $\begin{array}{r}26 \\
6 \\
16\end{array}$ \\
\hline
\end{tabular}



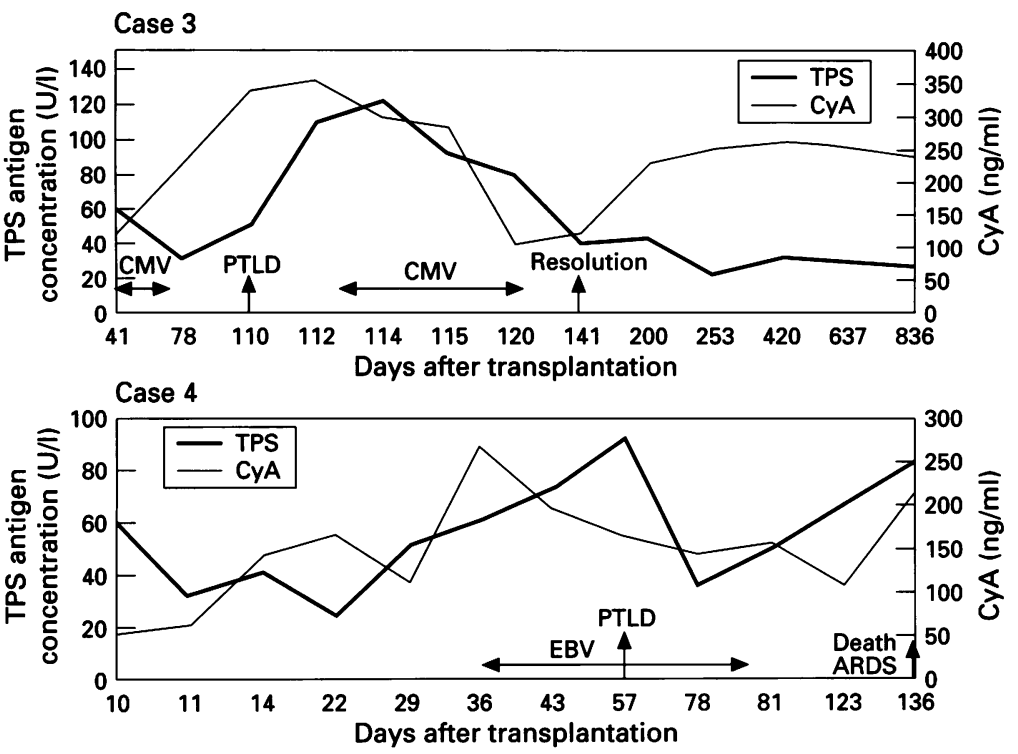

Figure 5 TPS antigen and CyA concentrations in cases 3 and 4. PTLD=post transplant lymphoproliferative disease; $A R D S=$ adult respiratory distress syndrome.
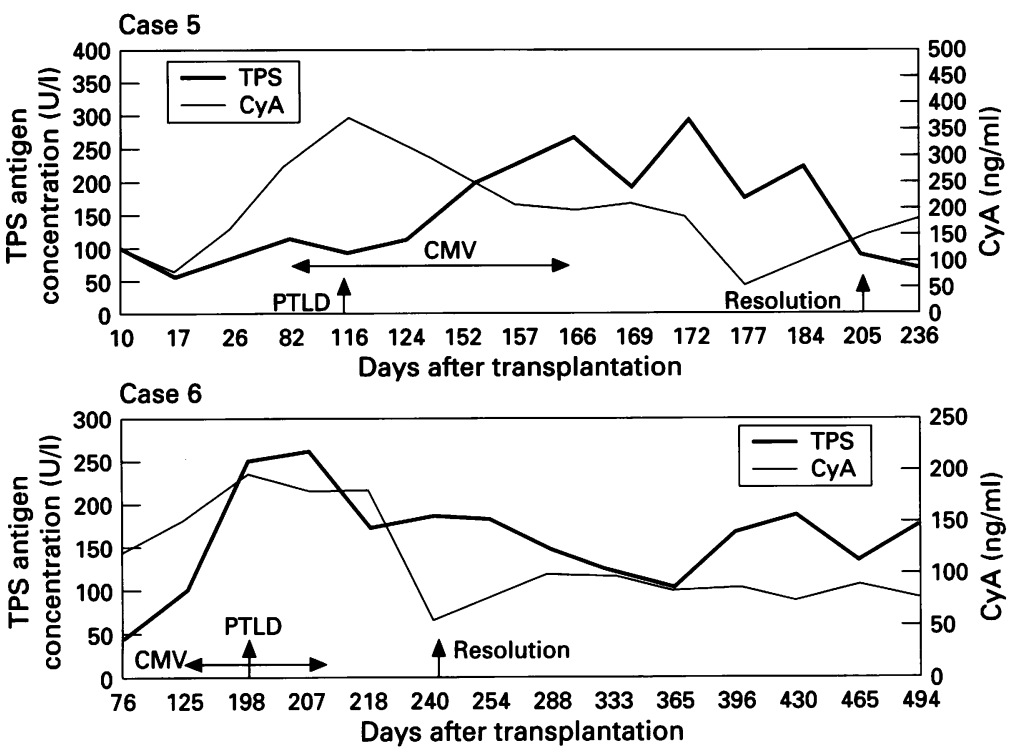

Figure 6 TPS antigen and CyA concentrations in cases 5 and 6. PTLD=post transplant lymphoproliferative disease.
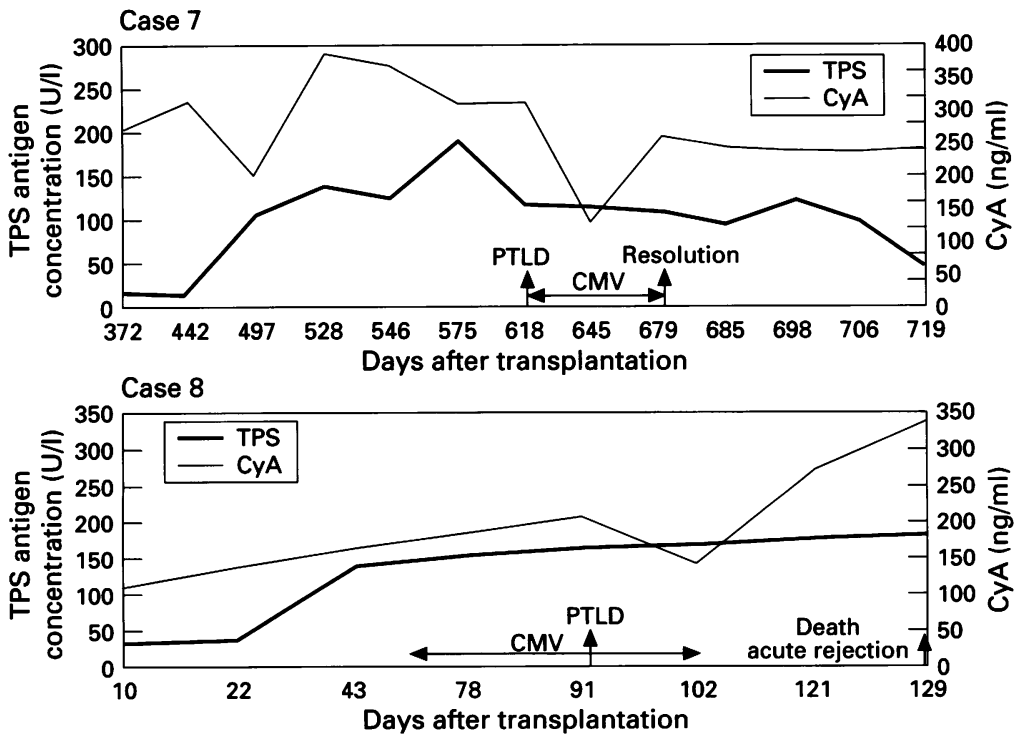

Figure 7 TPS antigen and CyA concentrations in cases 7 and 8. PTLD=post transplant lymphoproliferative disease. figs 1-3. Cut off values for the best diagnostic validities were $59 \mathrm{U} / 1$ (sensitivity $60 \%$, specificity 57\%) for controls $v$ infection, $158 \mathrm{U} / 1$ (sensitivity $100 \%$, specificity $67 \%$ ) for controls $v$ lymphoma and $151 \mathrm{U} / 1$ (sensitivity $76 \%$, specificity $67 \%$ ) for infection $v$ lymphoma.

Changes in TPS antigen and CyA concentrations in each recipient during follow up are illustrated in figs $4-7$. In six cases TPS antigen values increased 20-73 days (mean 42 days) before the diagnosis of post-transplant lymphoproliferative disease was confirmed by biopsy. In cases 5 and 7, however, TPS antigen concentrations decreased slightly before the diagnosis of post-transplant lymphoproliferative disease was established. Tumour regression was accompanied by a decrease in TPS antigen concentrations in all cases. In case 4, who died of progressive lymphoproliferative disease, TPS antigen concentrations decreased following a reduction in CyA immunosuppression, but increased as the patient's condition worsened. In case 8 , who died of an acute rejection episode, TPS antigen concentrations increased continuously until his death, although tumour regression was noted at necropsy.

\section{Discussion}

The cases presented here provide further evidence of a connection between CyA induced immunodeficiency and the occurrence of posttransplant lymphoproliferative disease. Although heart/lung transplant recipients have the highest incidence of post-transplant lymphoproliferative disease when compared with recipients of other transplanted organs, the $10.4 \%$ incidence rate recorded in this study is higher than that described elsewhere. ${ }^{17}$

An association between secondary EBV infection and post-transplant lymphoproliferative disease was found in case 4 . Reactivation of EBV infection from a subclinical reservoir of EBV DNA may have occurred following immunosuppression. The presence of CMV DNA in the lymphoproliferative tissues of cases 5 and 8 is an uncommon finding and raises questions concerning a possible role of $\mathrm{CMV}$ in posttransplant lymphoproliferative disease. It is possible that CMV infection and the development of post-transplant lymphoproliferative disease are unrelated. CMV and EBV belong to the same group of herpesviruses, both are DNA viruses, and the clinical symptoms they induce are very similar. These viruses, however, infect different cells. EBV infects lymphocytes and therefore the link between lymphoid proliferation and EBV is understandable. CMV infects epithelial cells and latent CMV may have been reactivated following immunosuppression.

TPS antigen is an unspecific proliferation marker and therefore a single TPS antigen concentration has a low predictive value. In the present study $83 \%$ of the patients had a true positive or true negative TPS value; however, $17 \%$ of patients had a TPS value within the normal range while developing post-transplant lymphoproliferative disease, 
or a high TPS value in the absence of lymphoma. Infection with CMV or EBV and post-transplant lymphoproliferative disease could not be distinguished by determining a single TPS antigen value (fig 1). By contrast, variations in TPS antigen concentrations determined over time allowed us to distinguish those patients at risk of developing a lymphoproliferative disease from controls, permitting the early reduction of the level of immunosuppression. In six patients TPS antigen concentrations increased about one month before post-transplant lymphoproliferative disease was diagnosed. Diagnosis, however, must still be confirmed by biopsy.

In conclusion, continuous monitoring of TPS antigen concentrations leads to the early detection of CyA induced lymphoproliferative disease, permitting early treatment and resulting in a better prognosis for the patient.

The authors are grateful to Sue Andrews (Syva (Europe)) for reviewing this manuscript.

1 Penn I, Hammond W, Brettschneider L, Starzl TE. Malignant lymphomas in transplantation patients. Transplant Proc 1969;1:106-12.

2 Starzl TE, Penn I, Halgrimson CG. Immunosuppression and malignant neoplasm. $N$ Engl $\mathcal{F}$ Med 1970;283:934

3 Penn I. Tumors arising in organ transplant recipients. $A d v$ Cancer Res 1978;28:31-61.

4 Penn I. Tumor incidence in human allograft recipients. Transplant Proc 1979;11:1047-54.

5 Yousem SA, Randhawa P, Locker J, Paradies IL, Dauber JA, Griffith BP, et al. Posttransplant lymphoproliferative disorders in heart-lung transplant recipients: primary presentation in the allograft. Hum Pathol 1989;20:361-9.
6 Klein G, Purtilo DT. Summary: symposium on Epstein-Barr virus induced lymphoproliferative diseases in immunodeficient patients. Cancer Res 1981;41:4302-4.

7 Saemundsen AK, Purtilo DT, Sakamato K, Sullivan JL, Synnerholm AC, Hanto D, et al. Documentation of Epstein-Barr virus infection in immunodeficient patients with life-threatening lymphoproliferative diseases by Epstein-Barr virus complementary RNA/DNA and viral DNA/DNA hybridization. Cancer Res 1981;41:4237-42.

8 Hanto DW, Gajl-Peczalska KJ, Frizzera G, Arthur DC Hanto DW, Gajl-Peczalska KJ, Frizzera G, Arthur DC,
Balfour HH, McClain K, et al. Epstein-Barr virus (EBV) induced polyclonal and monoclonal B-cell lymphoproliferative diseases occurring after renal transplantation. Ann Surg 1983;198:356-69.

9 Hanto DW, Frizzera G, Gajl-Peczalska KJ, Simmons RL. Epstein-Barr virus, immunodeficiency, and B-cell lymphoproliferation. Transplantation 1985;39:461-72.

10 Touraine JL, Bosi E, El Yafi MS, Chapuis-Cellier C, Blanc $\mathrm{N}$, Dubernard JM, et al. The infectious lymphoproliferative syndrome in transplant patients under improliferative syndrome in transplant patients under im-
munosuppressive treatment. Transplant Proc 1985;17: 96-8.

11 Ho M, Miller G, Atchinson RW, Breinig MK, Dummer JS, Andiman W, et al. Epstein-Barr virus infections and DNA hybridization studies in posttransplant lymphoma and lymphoproliferative lesions: The role of primary infection. $\mathcal{F}$ Infect Dis 1985;152:876-86.

12 Ho M, Jaffe R, Miller G, Brenig MK, Dummer JS, Makowka $\mathrm{L}$, Atchison RW, et al. The frequency of Epstein-Barr virus infection and associated lymphoproliferative syndrome after transplantations in children. Transplantation 1988;45:719-27.

13 Starzl TE, Nalesnik MA, Porter KA, Ho M, Iwatsuki S Griffith BP, Rosenthal JT, et al. Reversibility of lymphomas and lymphoproliferative lesions developing under Cycloand lymphoproliferative lesions developing unde

14 Björklund B, Björklund V. Antigenicity of pooled human malignant and normal tissues by cyto-immunological technique: presence of an insoluble, heat-labile tumor antigen. Int Arch Allergy 1957;10:153-84.

15 Björklund B. On the nature and clinical use of tissue polypeptide antigen. Tumor Diagnostik 1980;1:9-20.

16 Björklund B, Björklund V. The proliferation marker concept with tissue polypeptide specific antigen as a model. A preliminary report. $f$ Nucl Med Allied Sci 1990;34(Suppl 4):203.

17 Nalesnik MA, Jaffe R, Starzl TE, Demetris AJ, Porter $\mathrm{K}$, Burnham JA, et al. The pathology of post-transplant lymphoproliferative disorders occurring in the setting of cyclosporine A-prednisone immunosuppression. $A m \mathcal{f}$ cyclosporine A-predniso
Pathol 1988;133:173-92. 
to introduce molecular techniques into diagnostic clinical microbiology. It is in fact more suitable for a researcher who needs to compare organisms.

The techniques presented are diverse, ranging from antibiotic resistance profiles to random prime polymerase chain reaction and ligase chain reaction. Most of the chapters are of a very high standard providing clear advice but a number touch on areas which are too detailed to be handled in a brief chapter, notably, antibiotic resistance profiling or enzyme linked immunosorbent assay, which are too cursory to be truly useful. The editors have succeeded in bringing together text which is reasonably up to date although in this series not all of the techniques are molecular as illustrated by the excellent chapter on Bacteriocin and Bacteriophage typing. The authorship of this book is largely European despite its American format. It is undoubtedly a useful addition to the series and would be of use to research scientists.

\section{S GILLESPIE}

\section{Notices}

\section{CPA Annual Conference 1996 \\ Wednesday 13 March 1996}

Venue: Royal College of Physicians, 11 St Andrew's Place, London NW1 4LE (by kind permission of the Treasurer)

CPA (UK) Ltd is holding its fourth annual conference in March 1996. This year we have decided to use the forum to discuss CPA's findings in pathology in the first four year cycle and to look to the future of accreditation as we proceed to the second cycle of inspection visits.

Registration free: $£ 90$ (to include coffee, lunch and tea). The conference will be submitted for CPD and CME points.

For further information, please contact: CPA Central Office, Pathology Block, Children's Hospital, Sheffield S10 2TH. (Tel: 0114279 7472; fax: 01142780428. )

Forthcoming Royal College of Pathologists Symposia

Diagnostic pitfalls in histopathology/ cytopathology practice

Wednesday 7 February (1 day course)

Stress in the NHS

Thursday 18 March

Metabolic bone disease Thursday 18 April

What's new in development pathology Thursday 16 May

The spleen - who needs it? Wednesday 12 fune

Treatment of virus infections Wednesday 26 fune

For further information, please contact: Scientific Meetings Office, The Royal College of Pathologists, 2 Carlton House Terrace, London SW1Y 5AF. (Tel: 0171 930 5862.)

\section{The Third Annual Medical Design and Materials Conference}

25-27 March 1996

Venue: Olympia 2 and Conference Centre, London

Leading international experts will present up to the minute information and advice on the latest developments in materials for medical applications and innovative design techniques. Held in association with the Medical Design Technology Trade Show.

For further information, please contact: Sonja Lloyd, Advanstar Communications, Advanstar House, Sealand Road, Chester CH1 4RN. (Tel: 01244378 888; fax: 01244370011 .)

5th International Congress on Trace Elements in Medicine and Biology presents

Therapeutic Uses of Trace Elements

$$
\text { February 4-7 } 1996
$$

Main topics include: Therapeutic forms of trace elements; large epidemiological and intervention studies related to trace elements; trace element supplementation of population groups of differing ages; and trace elements, bone physiology and bone diseases, among others.

For further information, please contact: Madame A Alcaraz, Laboratoire de Biochimie C, CHURG, B.P. 217, F-38043 Grenoble Cedex 9, France (tel: (33) 76 7654 84; fax: (33) 767656 64).

\section{UMDS Dermatopathology Update} Friday, February 161996

Venue: St Thomas's Hospital, London Morning: Cutaneous Lymphoma Update

Speakers: R Willemze, A Norton, D Slater, N P Smith

Afternoon: Pre-circulated slide seminar

For further information, please contact: Dr P H McKee, Department of Histopathology, St Thomas's Hospital Medical School, Lambeth Palace Road, London SE1 7EH. (Tel: 01719289292 exn: 2295; fax 01714013661 .)

\section{United States FDA Medical Device \\ Update: Design Controls, GMP \\ Requirements and Marketing} Clearance

\section{0-23 May 1996}

Venue: Charles de Gaulle Hilton, Paris, France

An international meeting on FDA GMP and marketing regulations including the proposed new GMP requirements and how to comply with them. All three days will be presented by FDA's CDRH with a presentation by the European Commission. Sponsored by the French Government.

For further information, please contact: Sharon Goff, Advanstar Communications, Advanstar House, Sealand Road, Chester CH1 4RN. (Tel: 01244378 888; fax: 01244370011 .)

\section{Correction}

The incorrect figure was printed in figure 4 of the paper by Vogl et al ( $\mathcal{F}$ Clin Pathol 1995;48: 1039-44). The figure legend as printed is correct. The correct figure along with its legend is reproduced below.

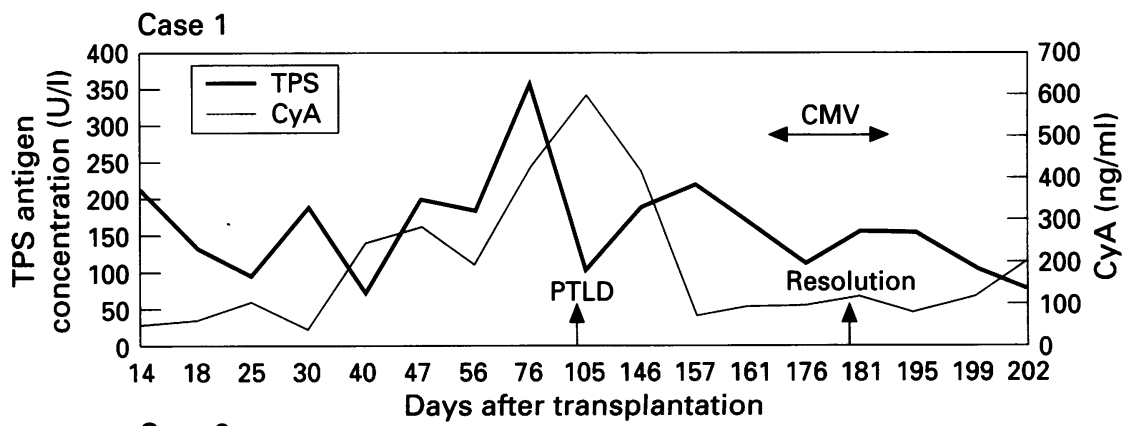

Case 2

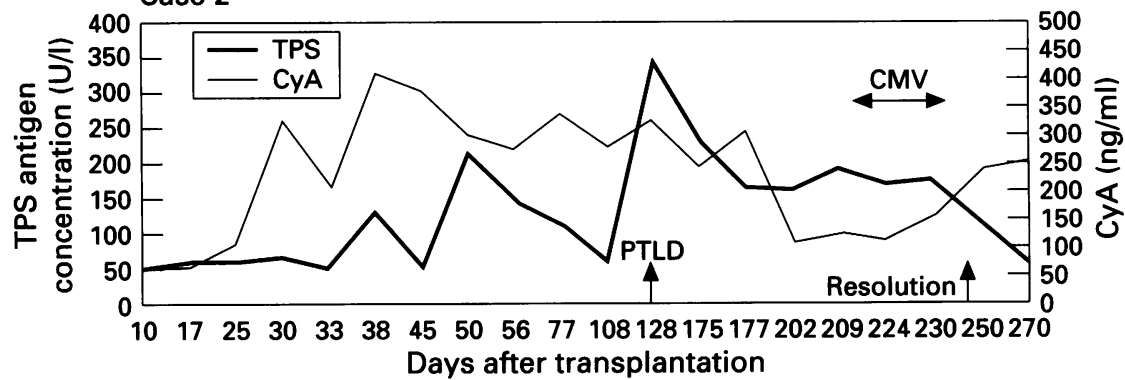

Figure 4 TPS antigen and CyA concentration in cases 1 and 2. PTLD=post transplant lymphoproliferative disease; $A R D S=$ adult respiratory distress syndrome. 